стях, предусмотренных штатами военного времени, или направления их для работы на должностях гражданского персонала Вооруженных Сил Российской Федерации, других войск, воинских формирований, органов и специальных формирований: Постановление Правительства РФ от 30.12.2006 г. № 852 / Собрание законодательства Российской Федерации. - М., 2007. - № 2. - Ст. 380.

11. Положение о порядке пребывания граждан Российской Федерации в мобилизационном людском резерве: Постановление Правительства РФ от 3.09.2015 г. № 933 / Собрание законодательства Российской Федерации. - М., 2015. - № 37. - Ст. 5147.

12. Положение о военных сборах: Постановление Правительства РФ от 29.05.2006 г. № 333 / Собрание законодательства Российской Федерации. - М., 2006. - № 23. - Ст. 2525.

13. Положения о воинском учете: Постановление Правительства РФ от 27.11.2006 г. № 719 / Собрание законодательства Российской Федерации. - М., 2006. - № 49. - Ст. 5220 (ч. II).

14. Положение о военно-врачебной экспертизе: Постановление Правительства РФ от 4.07.2013 г. № 565 / Собрание законодательства Российской Федерации. - М., 2013. № 28. - Ст. 3831.

15. Положения о военно-врачебной экспертизе: Постановление Правительства РФ от 25.02.2003 г. № 123 / Собрание законодательства Российской Федерации. - М., 2003. № $10 .-$ СТ. 902.

16. О создании путем учреждения федерального государственного казенного учреждения «Главный центр военно-врачебной экспертизы» Министерства обороны Российской Федерации»: Распоряжение Правитель- ства РФ от 3.07.2012 г. № 1163-р / Собрание законодательства Российской Федерации. М., 2012. - № 28. - Ст. 3950.

17. О порядке проведения военно-врачебной экспертизы и медицинского освидетельствования в Вооруженных Силах Российской Федерации: Приказ министра обороны РФ от 20.08.2003 г. № 200 // Бюлл. нормативных актов федеральных органов исполнительной власти. - М., 2001. - № 51.

18. О призыве граждан Российской Федерации, пребывающих в запасе, на военные сборы в 2016 году: Указ Президента РФ от 11.06.2016 г. № 283 // Рос. газета. - № 131. 17.06.2016.

19. О призыве граждан Российской Федерации, пребывающих в запасе, на военные сборы в 2017 году: Указ Президента РФ от 19.04.2017 г. № 179 // Рос. газета. - № 86. 21.04.2017.

20. О призыве граждан Российской Федерации, пребывающих в запасе, на военные сборы в 2018 году: Указ Президента РФ от 19.03.2018 г. № 114 // Рос. газета. - № 58. 21.03.2018.

21. Инструкция по обеспечению функционирования системы воинского учета граждан Российской Федерации и порядка проведения смотров-конкурсов на лучшую организацию осуществления воинского учета: Приказ министра обороны РФ от 18.07.2014 г. № 495 / Собрание законодательства Российской Федерации. - М., 2006. - № 49 (ч. II).

22. Об организации военно-врачебной экспертизы в Вооруженных Силах Российской Федерации: Метод. рекомендации (утверждены начальником Главного центра военноврачебной экспертизы МО РФ 11.04.2016 г., № $1 / 1 / 399$ ).

\title{
Л ЕНТАНОВОСТЕЙ
}

Расположенный в Санкт-Петербурге Военно-медицинский музей МО РФ проводит тематические дни, приуроченные ко Дню защитника Отечества.

Так, 23 и 24 февраля состоится экскурсия «Здоровье солдат и офицеров Российской армии залог Победы нашей страны».

23 февраля - лекция Андрея Кулика, краеведа, исследователя истории мировых войн «Непобедимая и легендарная. История побед Красной армии».

24 февраля - встреча абитуриентов и всех интересующихся со слушателями старших курсов Военно-медицинской академии имени С.М.Кирова в рамках проекта музея и ВМА им. С.М.Кирова «Как стать военным медиком».

24 февраля - лекция Андрея Кулика «Боеи, Ленинградского фронта: быт, внешний вид, отношение к врагу».

23 и 24 февраля будет работать выставка тематической недели «Санитарная сумка первая помощнииа солдата».

20-24 февраля посетители смогут увидеть мультимедийные проекты «Медики - Герои Советского Союза», «На страже здоровья воинов Красной Армии» и документальный фильм «Военная медицина на западном фронте Великой Отечественной войны» (1942).

Военно-медицинский музей МО РФ представляет экспозицию развития военной медицины в Российской армии, располагает уникальной коллекцией экспонатов и исторических артефактов.

Пресс-служба Западного военного округа, 22 февраля 2019 г. https://function.mil.ru/news_page/country/more.htm?id=12218528@egNews 